\title{
Immunolocalization of HLA-DR and Metallothionein on Amalgam Tattoos
}

\author{
Camila M.A. LEITE ${ }^{1}$ \\ Amanda S. BOTELHO ${ }^{1}$ \\ Jamila R. OLIVEIRA ${ }^{2}$ \\ Sérgio V. CARDOSO ${ }^{2}$ \\ Adriano M. LOYOLA ${ }^{3}$ \\ Ricardo S. GOMEZ ${ }^{2}$ \\ Ricardo R. VAZ ${ }^{2}$ \\ ${ }^{1}$ Dental Surgeon, Private Practice, Belo Horizonte, MG, Brazil \\ ${ }^{2}$ Department of Oral Surgery and Pathology, Faculty of Dentistry, Federal University of Minas Gerais \\ Belo Horizonte, $M G$, Brazil \\ ${ }^{3}$ Department of Pathology, Faculty of Dentistry,Federal University of Uberlândia, Uberlândia, MG, Brazil
}

\begin{abstract}
Despite studies concerning toxic reactions related to amalgam components in the literature, few studies have been devoted to evaluate local noxious effects of amalgam tattoos (AT) on biological tissues. In addition, little is known about activation of inflammatory cells by mucosa-implanted amalgam debris. Tissue reaction to AT depends on the particle size. Human leukocyte antigen DR (HLA-DR) is an activation marker of inflammatory cells associated with antigen presentation. Metallothioneins (MT) are proteins involved with metal detoxication, including mercury and silver. The purpose of the present study was to investigate the immunolocalization of HLADR and MT in AT with large or powdered particles. Paraffin-embedded AT tissue blocks were sectioned and subjected to immunohistochemistry for HLA-DR and MT localization. The results demonstrated a dense mononuclear inflammatory infiltrate associated with large and powdered debris and positivity for HLA-DR and MT in inflammatory cells. While blood vessel walls and connective fibers impregnated with powdered particles were negative for HLA-DR, they were positive for MT. In addition, wherever epithelial basement membrane impregnation by powdered amalgam particles was observed, a strong positivity for MT was detected. These findings demonstrate that residual elements of AT still have noxious local effects over tissues.
\end{abstract}

Key Words: amalgam tattoo, dental amalgam, HLA-DR, metallothionein, toxicity.

\section{INTRODUCTION}

Amalgam tattoo is a common finding in dental practice $(1,2)$. It is characterized by the deposit of restorative debris composed of a mixture of silver $(\mathrm{Ag})$, mercury $(\mathrm{Hg})$, tin $(\mathrm{Sn})$, zinc $(\mathrm{Zn})$, and copper $(\mathrm{Cu})$ in subepithelial connective tissue (3-5). It has been considered that such deposits are often due to mucosa abrasion by dental drilling or flossing during restorative procedures, implanting of residual fragment of amalgam following tooth extraction, deposit of amalgam into wounds during endodontic treatment, or di- rect propulsion of particles into mucosa by high-speed hand-pieces $(1,2)$. Clinically, it presents as an asymptomatic, ill-defined pigmented macula or patch that may occur anywhere on oral mucosa. Association with iatrogenic procedures has been considered an important skill for diagnosis $(1,2,6)$. When such association is doubtful or absent, histological differentiation from other pigments can be made by demonstration of amalgam metallic constituents within the fragments by refringence under polarized light, Lillie's melanin stain, electron microscopy, or energy dispersive $\mathrm{x}$-ray microanalysis $(5,7,8)$. Notwithstanding toxic effects of its

Correspondence: Prof. Dr. Ricardo Santiago Gomez, Laboratório de Patologia Experimental 3 - Sala 3203, Faculdade de Odontologia, Universidade Federal de Minas Gerais, Avenida Antônio Carlos 6627, 31270-901 Belo Horizonte, MG, Brasil. rsgomez@mail.odonto.ufmg.br 
components, amalgam tattoos have been considered innocuous lesions $(2,6,9,10)$, and surgical removal of the lesions has been indicated for aesthetic purposes or for differential diagnosis with other pigmented lesions, notably melanoma (6).

The tissue reaction to amalgam tattoo depends on the particle size. Powdered amalgam undergoes intracellular degradation by macrophages and giant cells in the soft tissue, with continuing mercury release. Residual particles containing mainly silver become diffusely distributed throughout the tissues. Larger fragments are surrounded initially by macrophages but are then progressively enclosed by a fibrous capsule, associated with a very slow breakdown process. Energy dispersive $\mathrm{x}$-ray microanalysis has shown that $\mathrm{Cu}$ and $\mathrm{Zn}$ are rapidly lost from the lesion, while $\mathrm{Hg}$ and $\mathrm{Sn}$ are lost slowly and only Ag remains in older lesions $(3,4)$. Despite studies concerning tissue reactions related to amalgam components in the literature, few studies have evaluated local activation of inflammatory cells by amalgam tattoos (10-14). In addition, little is known about local noxious effects of amalgam tattoos on biological tissues $(14,15)$.

Human leukocyte antigen DR (HLA-DR) is constituted by transmembranous glycoproteins. It is one of the major histocompatibility complex class II antigens (16). HLA-DR molecules are abundantly expressed in human monocytes and macrophages, and are responsible for antigen presentation to $\mathrm{CD}_{4}^{+} \mathrm{T}$ lymphocytes. Irritants are able to induce HLA-DR internalization by antigen-presenting cells (17). Metallothioneins (MT) are evolutionary conserved proteins associated with detoxication of heavy metals, among other likely cellular functions, and have been widely used as environmental markers of intoxication $(18,19)$. The only study accessing MT in amalgam tattoos observed higher immunoexpression in histiocytes adjacent to large globular particles, but very weak or even absent staining when related to fine amalgam particulate (15). The authors associated MT induction with the presence of $\mathrm{Hg}$, and considered the findings compatible with the temporal loss of this metal by the particles. No difference in the immunostaining of epithelial cells associated with amalgam dust was observed when compared with normal tissue (15). These findings are astonishing, since $\mathrm{Ag}$, the last component of amalgam tattoos, is able to induce MT expression, as well as other components of metallic restorations (20).
Considering that tissue reaction to amalgam tattoo depends on the particle size and HLA-DR antigens are activation markers of inflammatory cells associated with antigen presentation (16), together with the evidence that metallothioneins are proteins involved with metal detoxication, including $\mathrm{Hg}$ and $\mathrm{Ag}$ (19), the purpose of the present study was to investigate the immunolocalization of HLA-DR and MT in amalgam tattoos with large or powdered particles.

\section{MATERIAL AND METHODS}

Twenty-eight formalin-fixed, paraffin-embedded tissue blocks obtained from amalgam tattoos were retrieved. Hematoxylin and eosin stained new sections were used to evaluate the particle size and the associated inflammatory reaction. Three-micrometer sections were plated on silane coated slides and subjected to immunohistochemical assay with the biotin-streptavidinperoxidase method. Antigen retrieval was obtained by microwave treatment $(700 \mathrm{~W}, 3$ cycles of $5 \mathrm{~min}$ each) with $0.1 \mathrm{M}$ citrate (pH 6.0) or 1.0 M EDTA ( $\mathrm{pH} 8.2$ ) buffer for HLA-DR or MT, respectively. After cooling and washing in distilled water, the sections were immersed in 3\% methanol-hydrogen peroxide solution for 10 min to block endogenous peroxidase activity and subsequently incubated with normal swine serum. Then, samples were incubated with the primary antibodies (clone E9 anti-metallothionein, 1:100 dilution, and clone CR3/43 anti-HLA-DR, 1:100 dilution; both from Dako, Carpinteria, CA) for $18 \mathrm{~h}$ at $4{ }^{\circ} \mathrm{C}$ with $1 \%$ bovine serum albumin. After washing in $20 \mathrm{mM}$ Tris-HCl buffer (pH 7.4) containing $0.9 \% \mathrm{NaCl}$, the sections were sequentially incubated at room temperature with secondary biotinylated antibody (Dako) diluted 1:150 in Tris-HCl for $30 \mathrm{~min}$; washed with Tris-HCl (pH 7.4) twice for 10 $\mathrm{min}$; incubated for $30 \mathrm{~min}$ with horseradish peroxidaseconjugated streptavidin (Dako) diluted 1:50 in Tris$\mathrm{HCl}$; washed with Tris- $\mathrm{HCl}$ twice for $10 \mathrm{~min}$; incubated for $3 \mathrm{~min}$ with $0.01 \%$ diaminebenzidine tetrahydrochloride (Sigma, St. Louis, $\mathrm{MO}$ ) and $0.03 \% \mathrm{H}_{2} \mathrm{O}_{2}$ in 20 $\mathrm{mM}$ Tris- $\mathrm{HCl}$ buffer at $\mathrm{pH} 7.4$; rinsed in distilled water for $10 \mathrm{~min}$ and finally counterstained with hematoxylin. Different inflammatory tissues with known immunoreactivity for HLA-DR and the basal epithelial layer (MT positive) of the lesions were used as positive controls. Negative controls were obtained with the omission of the primary or secondary antibodies. 


\section{RESULTS}

Larger amalgam particles were generally associated with a dense inflammatory infiltrate of mononuclear cells with some foreign body giant cell formation. Mononuclear and giant cells were usually positive for HLA-DR (Figure 1a), with less conspicuous reaction for MT (Figure 1b). Powdered amalgam particles were associated with a decreased number of inflammatory cells presenting HLA-DR or MT immunopositivity. Pigmented dust was also found associated with blood vessel walls and connective tissue fibers. In these cases, endothelial cells were negative for HLA-DR, but sometimes positive for MT immunostaining (Figure 1c). The basal cell layer of the mucosa epithelium demonstrated positive immunostaining for MT in all samples. Impregnation of the epithelial basement membrane with powdered amalgam particles was associated with strong MT immunopositivity (Figure 1d).
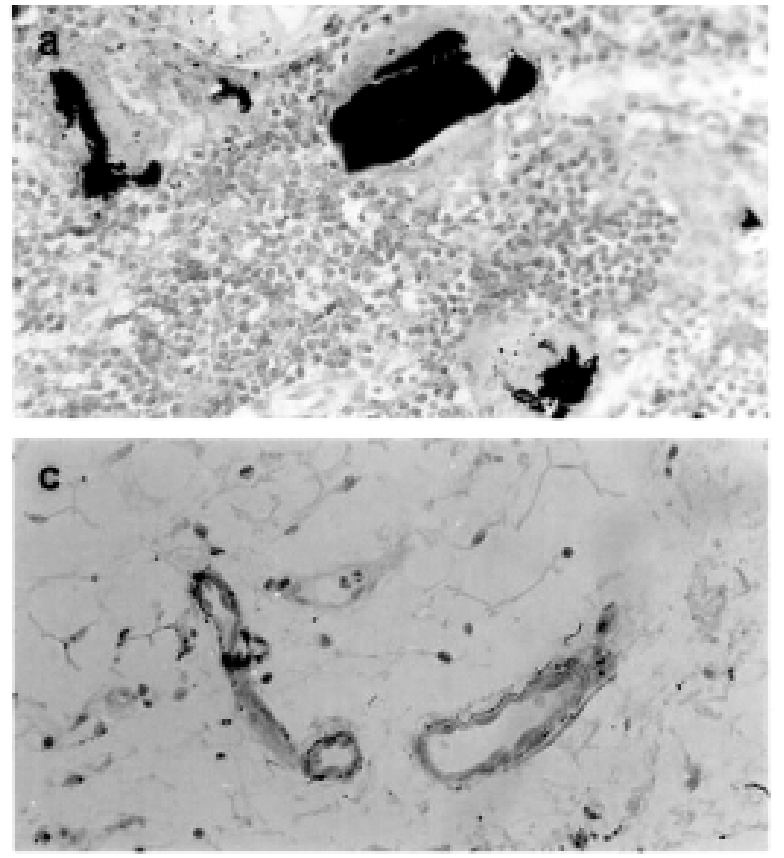

\section{DISCUSSION}

Amalgam tattoos have been considered innocuous lesions $(1,2,6,9)$. The toxicity of this compound has raised questions about its use in routine dental practice $(9,10,12,14)$. Local effects of amalgam debris over tissues have been sparsely studied $(13,15)$. The present results show that amalgam remnants are able to activate immunologic adaptive reaction and are also precipitants of the expression of an important detoxication protein.

HLA-DR is abundantly expressed on human monocytes and macrophages. It is one of the major histocompatibility complex class II-antigens and is responsible for antigen presentation to CD4-positive Tlymphocytes (16). It is reported that, albeit using distinct patterns of endocytosis, irritants are able to induce HLA-DR internalization by antigen-presenting cells as well as allergens (17). MT is a protein ubiquitously

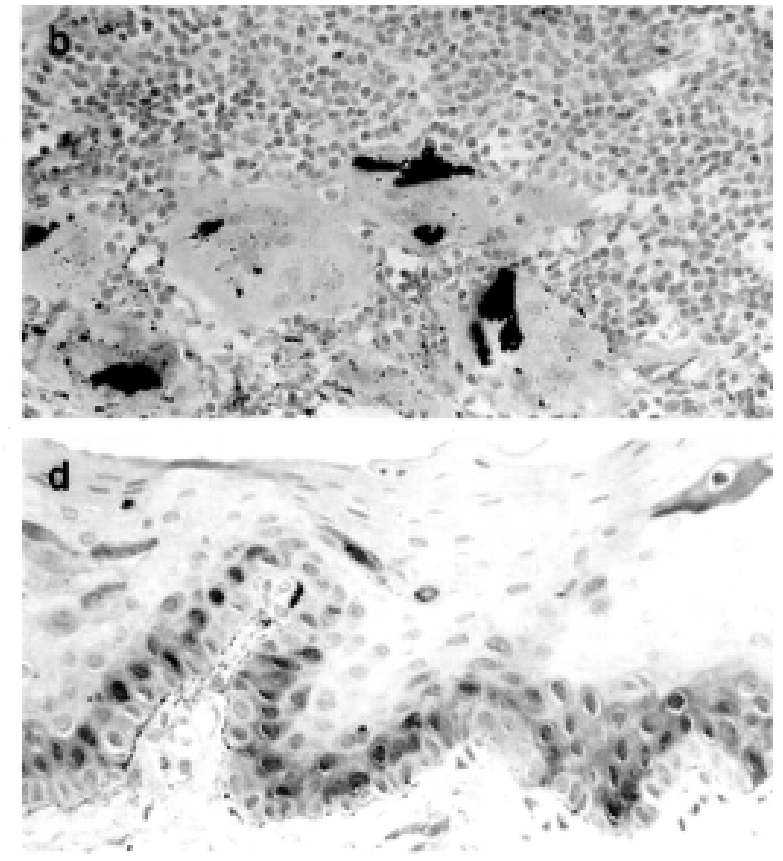

Figure 1. a) Large particles of amalgam associated with a dense inflammatory infiltrate of mononuclear cells with some foreign body giant cell formation. The inflammatory cells present showed positivity for HLA-DR (biotin-streptavidin-peroxidase stain, 400X). b) Large particles of amalgam associated with mononuclear inflammatory infiltrate and foreign body giant cells showing immunolabelling for metallothionein. Compared with HLA-DR, a less conspicuous immunoreaction can be observed (biotin-streptavidin-peroxidase stain, 400X). c) Powdered particles of amalgam impregnating blood vessel walls positive for metallothionein (biotin-streptavidinperoxidase stain, 400X). d) Basal and suprabasal cell layers of the mucosa epithelium demonstrating positive immunostaining for metallothionein associated with basement membrane impregnation by powdered amalgam particles (closed arrows); compare with nonimpregnated areas (open arrows) (biotin-streptavidin-peroxidase stain, 400X). 
distributed from single-cell organisms to human tissues, and has been used as a marker of intoxication in a variety of environmental casualties (19). It is a small protein with a high cysteine content that allows up to seven metal-binding sites, each one formed by four residues of thiolate ligands. Detoxication occurs when each of the residues binds with bivalent metals, freeradicals and other toxic compounds (18). MT immunoexpression in amalgam tattoos has been observed and interpreted as a protective reaction against local or systemic toxicity of amalgam components (15). Considering that different tissue reactions are found on amalgam tattoo according to its size and composition, in the present study we investigated the immunolocalization of HLA-DR and MT antigens in amalgam tattoo looking for insights to its pathogenesis and biological effects.

As mentioned, tissue reaction to amalgam tattoo depends on its particle size and composition $(2,3)$. While copper and zinc are rapidly lost from the area of the tattoo, mercury and tin are lost more slowly and finally silver remains permanent in the tissues. According to Eley (2), the process of intracellular digestion of amalgam in biological tissues results in the release of $\mathrm{Hg}$ and the formation of two kinds of secondary fine particles, those containing Sn and those containing Ag. Ionic $\mathrm{Hg}$ associates with biological ligands and becomes bound to protein. In this way, it would be probably transferred from the tissue fluid to the blood. The secondary particles containing $\mathrm{Sn}$ are progressively lost from the local lesion and are excreted by the kidneys and liver. Finally, the secondary particles containing Ag are degraded into silver cations or small molecules inside the phagocyting cells. Afterwards these cations gain access to the extracellular environment where they are re-aggregated into fine particles in the extracellular tissues. The association of these particles with blood vessel walls, basal lamina and connective tissue seemed to be responsible for the development and permanence of the tattoo. Forsell et al. (11) reported that the inflammatory reaction to amalgam tattoo becomes more severe as $\mathrm{Hg}$ content in the tissue increases, and that the latter was also correlated with Ag presence. Nadarajah et al. (13) also suggested that $\mathrm{Hg}$ accumulation may lead to altered expression of MHC class II determinants. In the present study it was found that inflammatory infiltrate associated with large and powdered debris were HLA-DR positive. There- fore, $\mathrm{Hg}$ may induce HLA-DR on macrophages during its degradation. While the blood vessel walls and connective fibers impregnated by the powdered particles were negative for HLA-DR, they were positive for MT. In addition, wherever epithelial basement membrane impregnation by powdered amalgam particles was observed, a strong positivity for MT was detected. These findings suggest that residual elements of amalgam tattoos, mainly containing Ag, still have noxious effects over tissues. MT immunoexpression may be a local tissue detoxication reaction against amalgam residues.

Lau et al. (15) reported higher MT immunoexpression in mononuclear cells adjacent to large globular particles compared to the very weak or even absent staining associated with fine amalgam particulate. It was associated by these authors with the presence and progressive loss of $\mathrm{Hg}$. They did not observe differences in the immunostaining of epithelial cells associated with amalgam dust when compared with normal tissue. Blood vessels and connective fibers containing debris were also negative for MT immunolocalization. Our results present a somewhat different picture. A weak but distinct reaction was observed in inflammatory cells, while basal and parabasal epithelial cells, blood vessels and connective fibers were associated with immunostaining when amalgam residues were present. A possible explanation for these results lays in the use of different antigen retrieval solution.

In conclusion, the present data demonstrate that residual elements of amalgam tattoo develop a noxious effect in biological tissues. However, we did not look for clinical implications of this finding for the management of the lesion, and further studies are necessary to elucidate this topic.

\section{RESUMO}

Poucos estudos têm investigado a toxicidade tecidual local das tatuagens por amálgama (TA), embora diversos trabalhos demonstrem efeitos nocivos desse material restaurador. Pouco se sabe sobre a ativação de células inflamatórias nesse tipo de lesão. A reação tecidual contra os restos de amálgama varia com o tamanho das partículas implantadas. $\mathrm{O}$ antígeno leucocitário humano DR (HLA-DR) está associado com a ativação de células inflamatórias, sendo relacionado à apresentação de antígeno. Metalotioneínas (MT) são proteínas envolvidas com neutralização de metais pesados, tais como mercúrio e prata. O objetivo do presente trabalho foi investigar a imunolocalização de HLA-DR e MT em TA compostas por depósitos teciduais de diferentes 
tamanhos. Cortes histológicos de lesões fixadas em formol e embebidas em parafina foram submetidos a técnica imunoistoquímica para a detecção dos antígenos mencionados. Os resultados demonstraram denso infiltrado inflamatório associado com partículas grandes ou pulverizadas, observandose presença de células HLA-DR e MT positivas. Paredes de vasos sangüíneos e fibras de tecido conjuntivo impregnadas por restos de amálgama foram negativas para HLA-DR, mas positivas para MT. Impregnação da membrana basal por partículas de amálgama correspondia a forte positividade para MT no epitélio. Esses resultados demonstram a existência de efeitos nocivos locais das TA sobre os tecidos.

\section{ACKNOWLEDGEMENTS}

This study was supported in part by grants from PRONEX, PADCT, FAPEMIG and CNPq, Brazil. Drs. R.S. Gomez and A.M. Loyola are research fellows of CNPq.

\section{REFERENCES}

1. Buchner A, Hansen LS. Amalgam pigmentation (amalgam tattoo) of the oral mucosa. A clinicopathologic study of 268 cases. Oral Surg Oral Med Oral Pathol 1980;49:139-147.

2. Owens BM, Johnson WW, Shuman NJ. Oral amalgam pigmentations (Tattoos): A retrospective study. Quintessence Int 1992;23:805-10.

3. Eley BM. Tissue reactions to implanted dental amalgam, including assessment by energy dispersive $\mathrm{x}$-ray micro-analysis. J Pathol 1982;138:251-72.

4. Eley BM, Garrett JR. Tissue reactions to the separate implantation of individual constituent of dental amalgam, including assessment by energy dispersive $\mathrm{x}$-ray microanalysis. Biomaterials 1983;4:73-80.

5. Daley TD, Gibson D. Practical applications of energy dispersive $\mathrm{x}$-ray microanalysis in diagnostic oral pathology. Oral Surg Oral Med Oral Pathol 1990;69:339-44.

6. Neville BW, Damm DD, Allen CM, Bouquot JE. Oral and maxillofacial pathology. $2^{\text {nd }}$ ed. EUA: WB Saunders, 2001.
7. Peters E, Gardner DG. A method for distinguishing between amalgam and graphite in tissue. Oral Surg Oral Med Oral Pathol 1986;62:73-76.

8. Mohr W, Görz E. Die assoziation von Silbergranula mit elastischen Fasern bei der Amalgamose der Mundschleimhaut. HNO 2001;49:454-457.

9. Holmstrup P. Reactions of the oral mucosa related to silver amalgam: a review. J Oral Pathol Med, 1991;20:1-7.

10. Wahl MJ. Amalgam: resurrection and redemption. Quintessence Int 2001;32:696-710.

11. Forsell M, Larsson B, Lungqvist A, Carlmark B, Johansson O. Mercury content in amalgam tattoos of human oral mucosa and its relation to local tissue reactions. Eur J Oral Sci 1998;106:5827.

12. Skoner JR, Wallace JA, Fochtman F, Moore PA, Zullo T, Hoffman D. Blood mercury levels with amalgam retroseals: a longitudinal study. J Endod 1996;22:140-141.

13. Nadarajah V, Neiders ME, Aguirre A, Cohen RE. Localized cellular inflammatory responses to subcutaneously implanted dental mercury. Toxicol Environ Health 1996;49:113-125.

14. Zhu Q, Safavi KE, Spangberg LS. Cytotoxic evaluation of rootend filling materials in cultures of human osteoblast-like cells and periodontal ligament cells. J Endod 1999;25:410-412.

15. Lau JC, Jackson-Boeters L, Daley TD, Wysocki GP, Cherian MG. Metallothionein in human gingival amalgam tattoos. Arch Oral Biol 2001;46:1015-1020.

16. Triantafilou K, Triantafilou M, Wilson KM, Fernandez N. Human major histocompatibility molecules have the intrinsic ability to form homotypic associations. Hum Immunol 2000;61:585598.

17. Rizova H, Carayon P, Barbier A, Lacheretz F, Dubertret L, Michel L. Contact allergens, but not irritants, alter receptor-mediated endocytosis by human epidermal Langerhans cells. Br J Dermatol 1999;140:200-9.

18. Palmiter RD. The elusive function of metallothionein. Proc Nat Acad Sci USA 1998;95:8428-30.

19. Coyle P, Philcox JC, Carey LC, Rofe AM. Metallothionein: the multipurpose protein. Cell Mol Life Sci 2002;59:627-647.

20. Murata M, Gong P, Suzuki K, Koizumi S. Differential metal response and regulation of human heavy metal-inducible genes. J Cell Physiol 1999;180:105-13. 